NASA Technical Memorandum 106677

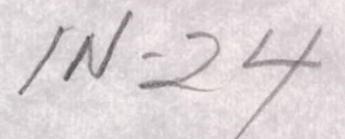

\title{
Refractory Oxide Coatings on SiC Ceramics
}

Kang N. Lee

Cleveland State University

Cleveland, Ohio

Nathan S. Jacobson and Robert A. Miller

Lewis Research Center

Cleveland, Ohio
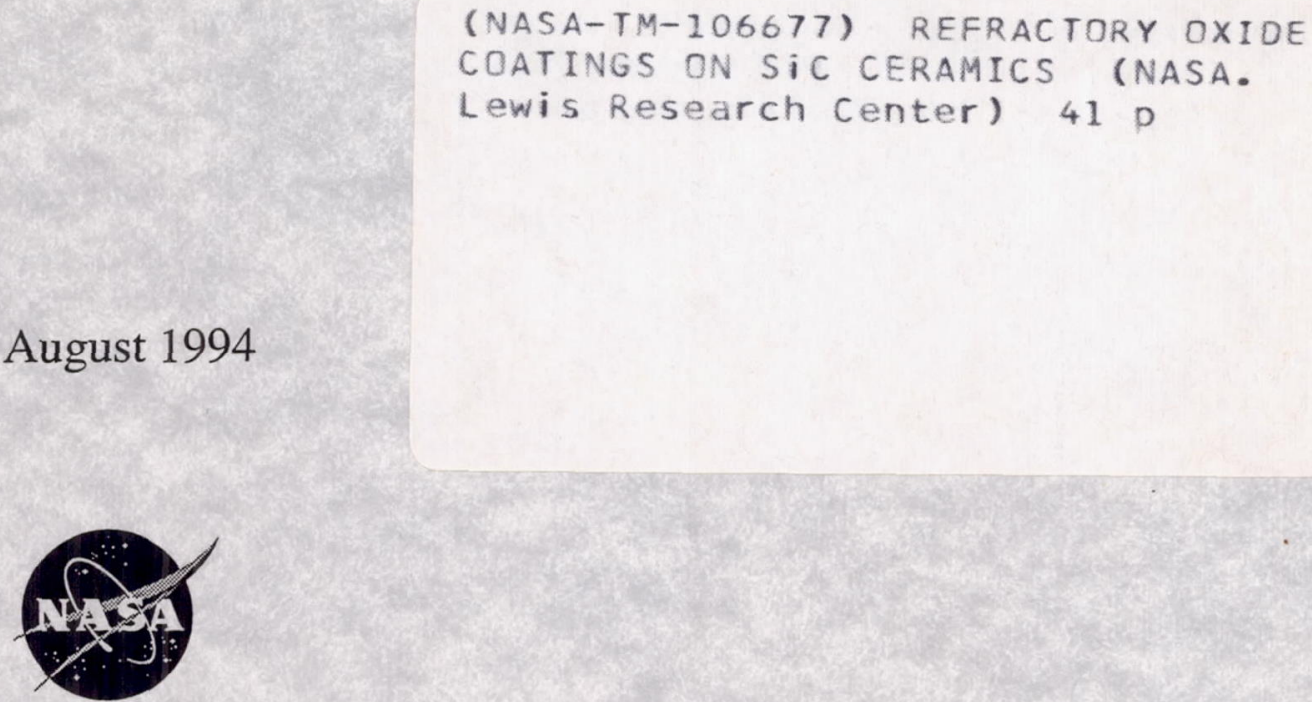

National Aeronautics and Space Administration 


\title{
Refractory oxide coatings on Sic ceramics
}

\author{
Kang N. Lee* \\ Cleveland State University \\ cleveland, ohio 44115
}

Nathan S. Jacobson and Robert A. Miller

National Aeronautics and space Administration

Lewis Research Center

Cleveland, ohio 44135

\section{Abstract}

Silicon carbide with a refractory oxide coating is potentially a very attractive ceramic system. It offers the desirable mechanical and physical properties of SiC and the environmental durability of a refractory oxide. The development of a thermal shock resistant plasma-sprayed mullite coating on Sic is discussed. The durability of the mullite/sic in oxidizing, reducing, and molten salt environments is discussed. In general, this system exhibits better behavior than uncoated Sic. Areas for further developments are discussed.

\section{Introduction}

Silicon-based ceramics are leading candidate materials for high temperature structural applications such as heat exchangers, advanced gas turbine engines, and advanced internal combustion engines. Their merits as high temperature materials include high

\footnotetext{
* NASA Resident Research Associate at Lewis Research Center
} 
temperature strength, high thermal conductivity, low density, and excellent oxidation resistance in clean oxidizing environments. Their oxidation resistance is due to the formation of a silica scale $\left(\mathrm{SiO}_{2}\right)$ having a very low oxygen permeability. ${ }^{1}$ However, durability at high temperature environments containing molten salts, ${ }^{2}$ water vapor, ${ }^{3-4}$ or a reducing atmosphere $e^{5-6}$ can limit their applications. Molten salts react with silica scale to form liquid silicates. oxygen readily diffuses through liquid silicates and rapidly oxidizes the substrate. ${ }^{2}$ High water vapor levels lead to hydrated silica species,,$^{3-4}$ such as $\mathrm{Si}(\mathrm{OH})_{4}(\mathrm{~g})$ and subsequent evaporation of protective scale. Complex combustion atmospheres containing oxidizing $\left(\mathrm{CO}_{2}, \mathrm{H}_{2} \mathrm{O}\right)$ and reducing $\left(\mathrm{CO}, \mathrm{H}_{2}\right)$ gases form $\mathrm{SiO}_{2}$ and then reduce it to $\mathrm{SiO}(g) .^{1,5-6}$ In situations with extremely low partial pressures of oxidant, direct formation of sio(g) occurs. ${ }^{1}$ All these reactions can potentially limit the formation of a protective silica scale and thus lead to an accelerated or a catastrophic degradation.

Due to these potential environmental limitations, there is a growing need to develop protection schemes for silicon-based ceramics. One approach is to apply a barrier coating which is environmentally stable in molten salts, water vapor, and/or reducing atmospheres. Refractory oxides such as mullite $\left(3 \mathrm{Al}_{2} \mathrm{O}_{3} \cdot 2 \mathrm{SiO}_{2}\right)$, yttria-stabilized zirconia $\left(\mathrm{ZrO}_{2}-\mathrm{Y}_{2} \mathrm{O}_{3}\right)$, or alumina $\left(\mathrm{Al}_{2} \mathrm{O}_{3}\right)$ are promising candidate coating materials because they are environmentally more stable than silica in these severe conditions. 
Refractory oxide coatings can also serve as thermal barrier coatings because of their low thermal conductivity. Thermal barrier coatings extend the lifetime and temperature capability of the substrate by reducing the substrate temperature. In addition to environmental stability, other key requirements for an adherent and durable barrier coatings include coefficient of thermal expansion (CTE) match and chemical compatibility with the substrate. Mullite in general meets all the requirements and thus appears most promising.

Solar Turbines, Inc. ${ }^{7}$ and oak Ridge National Lab. ${ }^{8}$ have done pioneering work on applying refractory oxide coatings on Sic by atmospheric pressure plasma spraying and slurry coating, respectively. Techniques were developed to roughen the surface which led to good adherence between the coating and substrate. A range of coatings were applied including mullite, alumina, yttria, yttria-stabilized zirconia, hafnia $\left(\mathrm{HfO}_{2}\right)$, cordierite $\left(2 \mathrm{MgO} .2 \mathrm{Al}_{2} \mathrm{O}_{3} \cdot 5 \mathrm{SiO}_{2}\right)$, and multilayer coatings consisting of these oxides. In general, mullite and mullite-based coatings such as mullite/alumina and mullite/yttria coatings were found to adhere and protect the best of the refractory oxide coatings tested. This is due to the close CTE match between mullite and Sic. However, even the mullite or mullite-based coatings tend to crack and debond on thermal cycling. Molten salt penetrates through the cracks and attacks the substrate, making them unsuitable for long-term applications. 
As mentioned, the substrate was roughened by etching or grit blasting. ${ }^{7-11}$ on a monolithic ceramic, this process leads to a strength degradation. However, as-plasma-sprayed coatings exhibited a strength distribution equivalent or superior to that of as-received Sic. ${ }^{12}$ The retained, or improved, strength of the asplasma-sprayed Sic was attributed to the good mechanical bond between the coating and SiC, presumably providing some load transfer to the coating from failure-initiating defects. ${ }^{12}$

The cracking and spallation of the early coatings were somewhat surprising given the close CTE between mullite and SiC. Conventionally plasma-spayed mullite coatings contain a large amount of amorphous phase mullite due to the rapid cooling of molten mullite on a substrate. ${ }^{9-11}$ The amorphous phase in the coating then crystallizes at $950-1000^{\circ} \mathrm{C}$ during a subsequent exposure in service.9-11,13 Crystallization of amorphous mullite accompanies a volummetric contraction. ${ }^{14}$ The stress associated with the volume change causes the severe cracking observed in the conventionallyprocessed mullite coatings. These findings led us to develop a new generation mullite coatings. In these coatings, the formation of amorphous mullite phase was eliminated by heating the substrate above the crystallization temperature during the plasma spraying. ${ }^{9-11}$ The new fully-crystalline coatings showed dramatically improved adherence, crack-resistance, and chemical stability under thermal cycling conditions. ${ }^{15}$ 
Coating properties can be further tailored to accommodate specific environmental requirements for various applications. One approach to modify coating properties is to apply an overlayer coating by using the mullite as a bond coat.

This paper describes the environmental durability of our new mullite coatings in air, oxidizing/reducing atmospheres, and molten salts. Possible overlay coatings and key issues related to the overlay coatings will also be briefly discussed.

\section{Experimental}

For the oxidation test in air, mullite coatings were applied onto the two large faces of $\operatorname{sic}^{* *}(2.5 \mathrm{~cm} \times 0.6 \mathrm{~cm} \times 0.15 \mathrm{~cm})$ or SiC/SiC composites ${ }^{* * *}(2.5 \mathrm{~cm} \times 1.25 \mathrm{~cm} \times 0.3 \mathrm{~cm})$ by atmospheric pressure plasma spraying. Twenty hr-cycle tests were performed at 1200 and $1300^{\circ} \mathrm{C}$ and one hr-cycle tests at $1200^{\circ} \mathrm{C}$. For the hot corrosion test, mullite coatings were applied onto all six faces of sic. Coated coupons were exposed to a burner rig in a molten sodium sulfate environment at $1000^{\circ} \mathrm{C}$. Tested specimens were mounted and polished for the post-test examination using scanning electron microscopy (SEM). Hot corrosion specimens were polished using kerosene to preserve water-soluble reaction products. Energy

\footnotetext{
** Hexoloy ${ }^{\mathrm{TM}}$, Carborundum, Niagara Falls, NY.

*** Dupont, Newark, DE.
} 
dispersive spectroscopy (EDS) was used for chemical analysis and $\mathrm{x}-$ ray diffraction (XRD) was used for phase identification.

\section{Oxidation Behavior in Air}

\section{Twenty Hour-Cycle Test}

Figures 1 and 2 compare the $20 \mathrm{hr}$-cycle oxidation kinetics of SiC/SiC composite coated with new mullite and SiC without a coating at 1200 and $1300^{\circ} \mathrm{C}$, respectively. As a comparison, the isothermal oxidation data of SiC/SiC composite ${ }^{16}$ are also shown in Fig 2. The isothermal oxidation rate agrees fairly well with the $20 \mathrm{hr}$-cycle oxidation rate, indicating the absence of scale spallation in the $20 \mathrm{hr}$-cycle test. Figures 1 and 2 show that the new mullite coating reduced the weight gain of SiC by a factor of about two at both temperatures, indicating an improvement in the adherence and thermal shock resistance of this coating. Also shown in Fig.2 is the oxidation kinetics of SiC/SiC composite coated with conventionally-sprayed mullite. The conventional mullite coating did not reduce the weight gain of Sic, which is ascribed to the coating's poor thermal shock resistance. ${ }^{7-11}$

Microscopic examination of the oxide scale is consistent with the weight change measurements. Figures $3 \mathrm{a}, 3 \mathrm{~b}$, and $3 \mathrm{c}$ compare the oxide scale cross sections of Sic without a coating, sic/sic composite coated with conventional mullite, and Sic/sic composite 
coated with new mullite, respectively, after sixty $20 \mathrm{hr}$-cycles at $1300^{\circ} \mathrm{C}$. Note that the oxide scale under the new mullite coating is substantially thinner than those on SiC without a coating and with the conventional mullite coating, confirming the weight change measurements. EDS analysis showed that the scale was in the form of aluminosilicate with varying composition across the thickness. ${ }^{15}$ This is attributed to the dissolution of excess alumina from the mullite coating into the silica scale. ${ }^{15}$

The surface and cross sections of conventional and new mullite coatings on SiC/SiC composites after sixty $20 \mathrm{hr}$-cycles at $1300^{\circ} \mathrm{C}$ are shown in Figs. $4 a-4 b$ and $5 a-5 b$, respectively. Note the substantially reduced number and size of the cracks in the new mullite coating compared with the conventional mullite coating. This again is indicative of the excellent thermal shock resistance of the new mullite coating. The lack of oxidation protection by the conventional mullite coating is due to the severe cracking. However, it should be noted that mullite coatings typically show through thickness cracks as seen in Figs. $5 \mathrm{a}$ and $5 \mathrm{~b}$. These cracks can cause thermal or thermomechanical fatigue cracks in the substrate in high frequency cycling over a long period. It should also be noted that the aluminosilica scale can deleteriously change interfacial properties such as CTE. Some voids are observed at $1300^{\circ} \mathrm{C}$ at the coating/substrate interface. The formation of voids are presumably due to the bubbling of gaseous $\mathrm{CO}$, generated as a result of the oxidation reaction ${ }^{1}$ and/or the reaction between the 
excess carbon in SiC and silica ${ }^{17}$. Substrate cracking due to through thickness cracks or the change of interfacial properties due to the formation of scale and/or voids may eventually control the lifetime of the coating.

\section{one Hour-Cycle Test}

In addition to the $20-\mathrm{hr}$ cycle tests, a series of $1 \mathrm{hr}$-cycle tests were performed. Figure 6 compares the $1 \mathrm{hr}$ cycle tests for uncoated SiC and the same SiC coated with the new mullite coating. Also shown is the $20 \mathrm{hr}$ cycle oxidation data for Sic.

There are several significant observations from the $1 \mathrm{hr}$ cyclic data. Note the lower weight gain in uncoated Sic for the 1 $\mathrm{hr}$ cycle as compared to the $20 \mathrm{hr}$ cycle. This suggests some scale spallation in the $1 \mathrm{hr}$ cyclic test, which is shown as a detached scale in the cross section (Fig. 7). This is consistent with the reduced rates observed in $1 \mathrm{hr}$ cycling as compared to isothermal and $5 \mathrm{hr}$ cycling for $\mathrm{SiC}$ at $1300^{\circ} \mathrm{C} .{ }^{18}$ Since the weight of the $1 \mathrm{hr}$ cyclic specimen did not exhibit abrupt changes, scale spallation is microscopic. Smooth weight changes in the presence of minor scale spallation are also observed in the cyclic oxidation of some superalloys, such as MA956, which forms a slow growing scale of $\alpha-$ $\mathrm{Al}_{2} \mathrm{O}_{3} .{ }^{19}$ The reasons for microscopic scale spallation in $1 \mathrm{hr}$ cycling as compared to the lack of scale spallation in $20 \mathrm{hr}$ cycling are not clear. It may be that $20 \mathrm{hr}$ cycling simply allows more time 
for the cracks generated on cooling to heal.

The issue in this paper is the effect of the mullite coating on $20 \mathrm{hr}$ and $1 \mathrm{hr}$ cyclic tests. Since $1 \mathrm{hr}$ cycles seem to lead to spallation, a good coating is particularly important in this case. sic coated with the new mullite showed a minor weight loss of about $0.15 \mathrm{mg} / \mathrm{cm}^{2}$ over $500 \mathrm{hr}$. The surface of mullite coating has a large number of spherical nodules with the size ranging from submicron to several micron. The minor weight loss is presumably due to the spallation of these small nodules from the surface during the high frequency cycling. Note that the weight loss was not observed in the lower frequency cycling ( $20 \mathrm{hr}$ cycle). The minor spallation is not expected to degrade the integrity of the coating for it is limited to the surface.

Figures $8 \mathrm{a}$ and $8 \mathrm{~b}$ compare the oxide scale on SiC without and with mullite coating after $5501 \mathrm{hr}$-cycle tests at $1200^{\circ} \mathrm{C}$, respectively. Even with scale spallation on the specimen without a coating, the oxide scale with the mullite coating was thinner than that on Sic without a coating. This is an indication of the excellent adherence and thermal shock resistance of the new mullite coating in the $1 \mathrm{hr}$ cycling. The new mullite coating improves oxidation resistance of $\mathrm{SiC}$ by reducing the oxygen transport as well as by preventing the scale spallation.

As already noted, mullite coatings develop through thickness 
cracks during long-term cycling (Fig. 9). These cracks can potentially initiate cracks in the substrate, leading to a strength degradation. Another source of problem may be the silica-rich alumino-silicate interfacial reaction layer, altering the close CTE match. Current research is aimed at addressing these issues.

\section{Behavior in Oxidizing/Reducing Gases}

Silica-forming ceramics can form the stable gaseous suboxide, Sio by two mechanisms ${ }^{1,5}$ : (1) Active oxidation where the total pressure of the oxidant is insufficient to form $\mathrm{SiO}_{2}$ and (2) oxidation/reduction where $\mathrm{SiO}_{2}$ is formed by the oxidizing gases in the atmosphere and immediately reduced to $\mathrm{sio}(g)$ by the reducing gases in the atmosphere.

The discussion here will focus on the behavior of mullite coatings and its ability to prevent sio(g) formation via the second mechanism, as mixed oxidizing/reducing environments are relatively common. Examples are $\mathrm{H}_{2} \mathrm{O} / \mathrm{H}_{2}{ }^{20}, \mathrm{CO}_{2} / \mathrm{CO}{ }^{21}$, and in a fuel-rich combustion chamber application ${ }^{22}$. In these cases, $\mathrm{SiO}(\mathrm{g})$ is generated by the following reactions:

$$
\begin{aligned}
& \underline{\mathrm{SiO}}_{2}+\mathrm{H}_{2}=\mathrm{SiO}(\mathrm{g})+\mathrm{H}_{2} \mathrm{O}(\mathrm{g}) \\
& \underline{\mathrm{SiO}}_{2}+\mathrm{CO}=\mathrm{SiO}(\mathrm{g})+\mathrm{CO}_{2}(\mathrm{~g})
\end{aligned}
$$


The underlined $\mathrm{SiO}_{2}$ means it is in solution with chemical activity less then unity. Clearly the lower the activity of $\mathrm{SiO}_{2}$, the lower the vapor pressure of sio. Table I lists some activities of $\mathrm{SiO}_{2}$ in alumina-saturated mullite. 23,24

Unfortunately, the activity of silica in mullite is not substantially less than unity. This gives only a slightly reduced vapor pressure of sio. Consider an actual application to illustrate the relative benefits of a mullite coating. Advanced low pollution combustors involve a staged concept, where fuel is first burned rich, then quenched, and finally burned lean. ${ }^{22}$ The rich burn portion presents a complex gas environment consisting of both oxidizing gases $\left(\mathrm{H}_{2} \mathrm{O}, \mathrm{CO}_{2}\right)$ and reducing gases $\left(\mathrm{H}_{2}, \mathrm{CO}\right)$. Computational thermodynamic analysis through the SOLGASMIX computer $\operatorname{code}^{25}$ can provide the expected vapor pressure of $\mathrm{SiO}$ over $\mathrm{SiO}_{2}$ as well as the vapor pressure of sio over alumina-saturated mullite.

In order to assess the durability of these materials, the actual flux leaving the surface is needed. Consider a cylindrical ceramic combustor liner, about $10 \mathrm{~cm}$ in diameter. The flux in mass/(unit area-time) leaving the walls will lie between the maximum possible flux into a vacuum (Langmuir flux) and the boundary-layer limited flux, depending on the flow characteristics. The Langmuir flux can be calculated from the Langmuir expression:

Here $J$ is the flux in mass/(unit area-time), $P$ is the vapor 


$$
J=\frac{P}{\sqrt{2 \pi M R T}}
$$

pressure of SiO, M is the molecular weight of Sio, $\mathrm{R}$ is the gas constant and $\mathrm{T}$ is the absolute temperature. The boundary layer limited flux can be calculated from the following correlation for a hollow cylinder ${ }^{26}$ :

$$
J=\frac{0.026 D_{S i O} P_{S i O}}{R T L}\left(\frac{v}{\rho D_{S i O}}\right)^{0.33}\left(\frac{\rho v L}{v}\right)^{0.8}
$$

Here $D_{\text {SiO }}$ is the diffusivity of Sio, $L$ is the diameter of the cylinder, $\nu$ is the viscosity of the gas, $\rho$ is the gas density, and $\mathrm{v}$ is the linear gas velocity. The results of a typical calculation are shown in Figure 10. This illustrates the large range between the Langmuir and boundary layer limited fluxes. It also shows the limited benefit of the mullite coating in this situation, suggesting the need for a coating of low silica activity or perhaps another refractory oxide.

\section{v. Corrosion by Molten Salt Deposits}

In a variety of combustion environments such as heat engines and heat exchangers, impurities in the fuel may lead to salt deposits. It is well-known from experience with metals and alloys that these deposits may lead to extensive corrosion. ${ }^{27}$ The 
chemistry of the salt deposit is critical and quite dependent on the application. This discussion will be limited to $\mathrm{Na}_{2} \mathrm{SO}_{4}$ deposits found in heat engines ${ }^{28}$, however many of the principles are applicable to other salt deposits as well.

A deposit of $\mathrm{Na}_{2} \mathrm{SO}_{4}$ decomposes by the reaction:

$$
\mathrm{Na}_{2} \mathrm{SO}_{4}=\mathrm{Na}_{2} \mathrm{O}+\mathrm{SO}_{3}
$$

The chemical activity of $\mathrm{Na}_{2} \mathrm{O}$ is a critical issue--a low $\mathrm{P}\left(\mathrm{SO}_{3}\right)$ sets a high activity of $\mathrm{Na}_{2} \mathrm{O}$ (basic molten salt) and a high $\mathrm{P}\left(\mathrm{SO}_{3}\right)$ sets a low activity of $\mathrm{Na}_{2} \mathrm{O}$ (acidic molten salt). Various factors such as fuel purity and carbon deposits influence the basicity of the salt deposit. Silica is readily attacked by basic molten salts. This leads to a low melting liquid sodium silicate, which is no longer a barrier to inward oxygen diffusion and to rapid oxidation and corrosion ${ }^{1,2}$. The key reaction is:

$$
\mathrm{SiO}_{2}+\mathrm{Na}_{2} \mathrm{O}=\mathrm{Na}_{2} \mathrm{O} .2\left(\mathrm{SiO}_{2}\right)
$$

There are a number of sodium silicates with melting points as low as $1013 \mathrm{~K}^{29}$

A lower activity of the $\mathrm{SiO}_{2}$ species will limit the above reaction. However, as shown in Table $I$, the activity of $\mathrm{SiO}_{2}$ in mullite is not substantially less than unity. This lowered activity 
of silica is not enough to limit corrosion. However the presence of alumina leads to ternary sodium-alumino-silicate compositions, which have higher melting points than sodium silicates. The lowest melting sodium silicate composition melts at about $1336 \mathrm{~K}$.

Figure 11 shows the $\mathrm{Na}_{2} \mathrm{O}-\mathrm{Al}_{2} \mathrm{O}_{3}-\mathrm{SiO}_{2}$ phase diagram ${ }^{29}$ with compatibility triangles at $1273 \mathrm{~K}$. The addition of $\mathrm{Na}_{2} \mathrm{O}$ to this system as a corrosive deposit is shown by the line drawn from mullite to pure $\mathrm{Na}_{2} \mathrm{O}$. Different points along this line correspond to different activities of $\mathrm{Na}_{2} \mathrm{O}$. Using the available thermodynamic data $23,24,30$, the activity along this line can be calculated. Thus for a given $\mathrm{a}\left(\mathrm{Na}_{2} \mathrm{O}\right)$, product phases may be predicted. Figure 11 shows a series of compatibility triangles with inferred joins. ${ }^{29}$ In the case of a high $\mathrm{a}\left(\mathrm{Na}_{2} \mathrm{O}\right)$ at the gas/solid interface, a gradient of $\mathrm{a}\left(\mathrm{Na}_{2} \mathrm{O}\right)$ to the mullite is predicted and, in theory, many phases could be formed. However, in practice, kinetic factors may limit this. Also many of the silicates form solid solutions, which are not considered in a compatibility triangle type calculation. Nonetheless, phases can be predicted to provide general guidelines.

Table II shows the results for several corrosion tests on pure mullite and mullite coated ceramics. ${ }^{31}$ The $\mathrm{P}\left(\mathrm{SO}_{3}\right)$ above the deposit was calculated from the NASA Chemical Equilibrium Code ${ }^{32}$ which is a free-energy minimization code particularly suited to fuels and oxidants. The laboratory experiments were done by air-brushing a thin film of salt on a coupon and heating with an overpressure of 
a particular gas to set an activity of $\mathrm{Na}_{2} \mathrm{O}$. Products were identified by X-ray diffraction and in the case of the mullite $/ \mathrm{Na}_{2} \mathrm{CO}_{3}$ sample, quantitative EDS.

Although the thermodynamic predictions provide guidelines, the lack of agreement (as seen in Table II, phases predicted vs. phases observed) suggests other factors must be considered. The refractory corrosion literature indicates that the composition $\mathrm{Na}_{2} \mathrm{O} \cdot \mathrm{Al}_{2} \mathrm{O}_{3} \cdot 6 \mathrm{SiO}_{2}$ is rarely seen $^{33}$, which implies a kinetic barrier. As mentioned, these products are all solid and it may be that the formation of a solid product from liquid $\mathrm{Na}_{2} \mathrm{SO}_{4}$ and mullite is simply quite slow. The important point is that acidic $\mathrm{Na}_{2} \mathrm{SO}_{4}$, as is typical of deposits in a Jet fuel burner, produces only limited reaction. The basic molten salt produced a $15 \mu \mathrm{m}$ layer of sodiumalumino-silicate solid solution.

Figure $12 a$ shows a cross section of the mullite sample corroded in the burner. It is compared to an uncoated Sic sample, shown in Figure 12b. Clearly the coated sample does not show the massive corrosion the uncoated sample does. This is attributed to the lack of liquid products in the mullite $/ \mathrm{Na}_{2} \mathrm{O}$ case. Examination of the sample in Figure 12 a shows the sodium sulfate deposited in small regions on the surface of the sample. Further examination of the mullite/sic interface revealed the presence of some sodium at this interface. Over long times this could lead to sodium silicate formation in this region and eventual debonding of the coating. 
Additional coating layers may be a solution to this problem.

\section{Multilayer coatings}

As has been noted, through thickness cracks can potentially initiate substrate cracking, leading to a strength degradation. The silica activity in mullite is about 0.4 , but sufficient to lead to limited reactions in some corrosive environments. An interfacial reaction zone may deleteriously change the interfacial properties. Therefore, it may be desirable to further modify the coating. One approach to modify the coating properties is to apply an overlay coating to seal through thickness cracks and/or enhance the environmental durability.

Alumina and zirconia-yttria are the most promising candidates for overlay coating materials. Compared with mullite, alumina and zirconia-yttria are less reactive in molten salt or water vapor and more durable in reducing atmospheres. ${ }^{34}$ Besides the superior environmental durability, they will also provide an added thermal barrier capability because of their low thermal conductivities.

There are, however, issues that must be addressed in the use of an overlay coating. One issue is the CTE mismatch between the mullite and the overlay coating. The large CTE mismatch between mullite $\left(5.4 \times 10^{-6} \mathrm{C}^{-1}\right)^{11}$ and alumina $\left(9 \times 10^{-6} \mathrm{C}^{-1}\right)^{35}$ or zirconia-yttria $\left(12 \times 10^{-6} \mathrm{C}^{-1}\right)^{35}$ can induce a high residual stress and result in poor 
thermal shock resistance. The concept of compositionally-graded coatings can be used to reduce the CTE mismatch in multilayer coatings. ${ }^{36}$

Another issue is the phase stability of the overlay coating. Alumina and zirconia have several different crystallographic polymorphs. $37-40$ The phase distribution, which is a function of temperature and cooling rate, significantly affects the thermal shock resistance and thus the lifetime of the coating. In zirconia coatings, stabilizing the tetragonal phase by alloying with yttria limits the detrimental phase transformation. ${ }^{37-38}$ In alumina coatings, phase transformation and the resultant volume change is a critical issue. ${ }^{39-40}$ Plasma-sprayed alumina coatings are generally metastable gamma-alumina with a small amount of alpha-alumina. ${ }^{39}$ Extended exposure of gamma-alumina coatings to temperatures above $1200^{\circ} \mathrm{C}$ results in complete transformation to alpha-alumina. ${ }^{39}$ This transformation is accompanied by a volummetric contraction, causing fragmentation of the structure and cracking..$^{40}$ Therefore, it may be necessary to deposit the coating in the form of the alpha-alumina phase to prevent the detrimental phase transformation during service.

VII. Summary

Mullite coatings clearly limit oxidative consumption of SiC, wiht excellent adherence and thermal shock resistance. This is 
particularly true in the case of cyclic oxidation. In an oxidation/reduction situation, mullite coating offers only a limited benefit. Coated SiC shows substantially improved protection against molten salt corrosion for short term exposure. However, the penetration of salt into the coating/Sic interface is an issue for long term operation. Multilayer coatings offer a potential solution to some of these issues.

Acknowledgements

The authors would like to thank Charles A. Barrett at NASALewis Research Center for carrying out one hour-cycle tests.

\section{References}

1. N.S. Jacobson, "Corrosion of Silicon-Based Ceramics in Combustion Environments," J. Am. Ceram. Soc. 76(1), 3-28 (1993).

2. N.S. Jacobson, J.L. Smialek, and D.S. Fox, "Molten Salt Corrosion of $\mathrm{SiC}$ and $\mathrm{Si}_{3} \mathrm{~N}_{4}$," Handbook of Ceramics and Composites Vol.1, N.P. Cheremisinoff, ed., Marcel Dekker, New York and Basel, 99-135 (1990).

3. A. Hashimoto, "The Effect of $\mathrm{H}_{2} \mathrm{O}$ gas on volatilities of PlanetForming Major Elements: I. Experimental Determination of Thermodynamic Properties of $\mathrm{Ca}-, \mathrm{Al}$, and $\mathrm{Si}$-hydroxide gas molecules and its application to the solar nebula," Geochimica et Cosmochimica Acta 56, 511-532 (1992).

4. E.J. Opila, "The Oxidation of SiC in 0.5 Atmosphere Water Vapor," Presented at the ECS 1993 Fall Meeting, New orleans, LA. (1993).

5. E.J. Opila and N.S. Jacobson, "Sio(g) Formation from SiC in Mixed oxidizing/Reducing Gases," (Submitted to Oxid. Met.)

6. D.S. Fox, Unpublished Research, NASA-Lewis Research Center, Cleveland, Ohio (1993). 
7. J.I. Federer, "Alumina Base Coatings for Protection of SiC Ceramics," J. Mater. Eng. 12(2), 141-149 (1990).

8. J.R. Price, M. van Roode and C. Stala, "Ceramic oxide-coated Silicon Carbide for High-Temperature Corrosive Environments," Key Engineering Materials 72-74, 71-84 (1992).

9. K.N. Lee, R.A. Miller, and N.S. Jacobson, "Plasma-Sprayed Mullite Coatings on Silicon-Based Ceramics," U.S. Patent Application Serial Number 08/031,444.

10. K.N. Lee, R.A. Miller, and N.S. Jacobson, "Development of Thermal Shock Resistant Mullite Coatings on Silicon Carbide," Advances in Ceramic-Matrix Composites, N.P. Bansal, Ed., Ceram. Trans. 38, 565-576 (1993).

11. K.N. Lee, R.A. Miller, and N.S. Jacobson, "A New Generation of Plasma-sprayed Mullite coatings on SiC," (submitted to $J$. Am. Ceram. Soc.).

12. D.P. Butt, J.J. Mecholsky, Jr., M. van Roode, and J.R. Price, "Effects of Plasma-sprayed Ceramic coatings on the Strength Distribution of Silicon Carbide Materials," J.Am. Ceram. Soc. $73(9), 2690-96$ (1990).

13. T. Takeshi and R. Roy, "Rapid Crystallization of $\mathrm{SiO}_{2}-\mathrm{Al}_{2} \mathrm{O}_{3}$ Glasses," J.Am. Ceram. Soc. 56(12), 639-44 (1973).

14. S. Somiya and Y. Hirata, "Mullite Powder Technology and Applications in Japan," Bull. Am. Ceram. SoC. 70(10), 1624-32 (1991).

15. K.N. Lee and R.A. Miller, "Long-Term Durability of MulliteCoated Silicon-Based Ceramics," (Submitted to Ceramic Engineering \& Science Proceedings)

16. E.J. Opila, Unpublished Research, NASA-Lewis Research Center, Cleveland, Ohio (1993).

17. N.S. Jacobson, K.N. Lee, and D.S. Fox, "Reactions of Silicon Carbide and Silicon(IV) Oxide at Elevated Temperatures," J. Am. Ceram. Soc. 75(6), 1603-11 (1992).

18. E.J. Opila, D.S. Fox, and C.A. Barrett, "Cyclic oxidation of Monolithic $\mathrm{SiC}$ and $\mathrm{Si}_{3} \mathrm{~N}_{4}$ Materials," Proceedings of the 17 th Annual conference on Composites and Advanced Ceramic Materials, The American Ceramic Society, 367-374 (1993).

19. K.N. Lee, V. Arya, G. Halford, and C.A. Barrett, "Cyclic oxidation of MA956 and Continuous Sapphire Fiber-Reinforced MA956 Composite at $1100-1200^{\circ} \mathrm{C}$," (in preparation). 
20. H.E. Kim and D.W. Readey, "Active oxidation of SiC in Low DewPoint Hydrogen above $1400^{\circ} \mathrm{C}$," in Silicon Carbide '87, ed. by J.D. Cawley and C.E. Semler, American Ceramic Society, Westerville, OH, 1987, pp. 301-312.

21. T. Narushima, T. Goto, Y. Yokoyama, Y. Iguchi, and T. Hirai, "High Temperature Active Oxidation of Chemically Vapor Deposited Silicon Carbide in $\mathrm{CO}-\mathrm{CO}_{2}$ Atmosphere," J. Am. Ceram. Soc., 76 [10] 2521-2524 (1993).

22. N. S. Jacobson, "High Temperature Durability Considerations for HSCT Combustor," NASA Technical Paper 3162, 1992.

23. I. Barin, Thermochemical Properties of Inorganic Substances, Parts I and II, VCH, Weiheim, Germany, 1989.

24. M.W. Chase, Jr., et. al., eds., JANAF Thermochemical Tables, 3rd Edition, American Chemical Society and American Physical Society, New York, NY, 1985.

25. T.M. Besmann, "SOLGASMIX-PV: A Computer Program to Calculate Equilibrium Relationships in Complex Chemical systems," ORNL/TM5775, Oak Ridge National Laboratory, April 1977.

26. G.H. Geiger and D.R. Poirier, Transport Phenomena in Metallurgy, Addison-Wesley, 1974, p. 244.

27. F.S. Pettit and C.S. Giggins, "Hot Corrosion," pp. 327-54 in Superalloys, ed. by C. T. Sims, N. S. Stoloff, and W. C. Hagel, Wiley, New York, 1987.

28. N. S. Jacobson, "Sodium Sulfate: Deposition and Dissolution of Silica," oxid. Met. 31 [1/2] 91-103 (1989).

29. E. M. Levin, C. R. Robbins, and H. F. McMurdie, Phase Diagrams for Ceramists, American Ceramic Society, Columbus, OH, 1964, p. 501 .

30. F. A. Elrefaire and W. W. Smeltzer, "The stability of $\beta-\mathrm{Al}_{2} \mathrm{O}_{3}$ $\left(\mathrm{Na}_{2} \mathrm{O} .11 \mathrm{Al}_{2} \mathrm{O}_{3}\right)$ in oxygen Atmospheres, "J. Electrochem. Soc. 128 [7], 1443 (1981).

31. N.S. Jacobson, K.N. Lee, and T. Yoshio, "Corrosion of Mullite and Mullite coated SiC by Molten Salts," in preparation for J. Am. ceram. Soc.

32. S. Gordon and B. J. McBride, "Computer Program for Calculation of Complex Chemical Equilibrium Compositions, Rocket Performance, Incident and Reflected Shock, and Chapman-Jouguet Detonations," NASA SP-273, 1971. 
33. R.E. Farris and J.E. Allen, "Aluminous Refractories-Alkali Reactions," Iron and steel Engineer, 67-74, 1973,

34. A.K. Misra, "Thermodynamic Analysis of Chemical stability of Ceramic Materials in Hydrogen Containing Atmosphere at High Temperatures," NASA Contractor Report 4271 (1990).

35. Y.S. Touloukian, R.K. Kirby, R.E. Taylor, and T.Y. R. Lee, Thermophysical properties of Matter Vol. 13, (IFI/Plenum, New YorkWashington, 1977).

36. T. Nagano and F. Wakai, "Fabrication of zirconia-alumina functionally gradient materials by superplastic diffusion bonding," J. Mat. Sci. 28, 5793-5799 (1993).

37. R.A. Miller, J.L. Smialek, and R.G. Garlick, "Phase stability in Plasma-Sprayed, Partially Stabilized Zirconia-Yttria," Advances in Ceramics Vol. 3, American Ceramic Society, 1981.

38. R.A. Miller, R.G. Garlick, and J.L. Smialek, "Phase Distributions in Plasma-Sprayed Zirconia-Yttria," Am. Ceram. Soc. BuI. 62(12), 1355-1358 (1983).

39. G.N. Heintze and S. Uematsu, "Preparation and structure of Plasma-Sprayed $\gamma$ - and $\alpha-\mathrm{Al}_{2} \mathrm{O}_{3}$ Coatings," Surface and coatings Technology, 50, 213-222 (1992).

40. J. Skogsmo and M. Halvarsson, "Microstructural Study of the $\kappa^{-}$ $\mathrm{Al}_{2} \mathrm{O}_{3}$ to $\alpha-\mathrm{Al}_{2} \mathrm{O}_{3}$ transformation in CVD k- $\mathrm{Al}_{2} \mathrm{O}_{3}$," Surface and coatings Technology, 54/55, 186-192 (1992). 
Table I. Activities of $\mathrm{SiO}_{2}$ in $\mathrm{Al}_{2} \mathrm{O}_{3}$ saturated mullite.

\begin{tabular}{||l|l|}
\hline Temperature $(\mathrm{K})$ & \multicolumn{1}{|c|}{$\mathrm{a}\left(\mathrm{SiO}_{2}\right)$} \\
\hline \hline 1200 & .488 \\
\hline 1400 & .424 \\
\hline 1600 & .382 \\
\hline 1800 & .353 \\
\hline
\end{tabular}


Table II. Corrosion tests of mullite coated SiC and pure mullite at $1273 \mathrm{~K}$.

\begin{tabular}{|c|c|c|c|c|}
\hline Material & Corrodent & $\mathrm{a}\left(\mathrm{Na}_{2} \mathrm{O}\right)$ & $\begin{array}{c}\text { Phases* } \\
\text { Predicted }\end{array}$ & $\begin{array}{c}\text { Phases } \\
\text { Observed }\end{array}$ \\
\hline $\begin{array}{l}\text { Mullite } \\
\text { coated } \\
\text { Sic }\end{array}$ & $\begin{array}{l}\text { Burner--2 } \\
\text { ppm Na + } \\
0.05 \% \mathrm{~S} \\
\text { Fuel }\end{array}$ & $1.2 \times 10^{-10}$ & $\begin{array}{l}\text { Mullite, } \\
\mathrm{Al}_{2} \mathrm{O}_{3}, \\
\mathrm{NAS}_{6}, \mathrm{NAS}_{2}\end{array}$ & $\begin{array}{l}\text { Mullite, } \\
\mathrm{Na}_{2} \mathrm{SO}_{4}\end{array}$ \\
\hline Mullite & $\begin{array}{l}\text { Burner--2 } \\
\text { ppm Na }+ \\
0.05 \% \mathrm{~S} \\
\text { Fuel }\end{array}$ & $1.2 \times 10^{-10}$ & $\begin{array}{l}\text { Mullite, } \\
\mathrm{Al}_{2} \mathrm{O}_{3}, \\
\mathrm{NAS}_{6}, \mathrm{NAS}_{2}\end{array}$ & $\begin{array}{l}\mathrm{Mullite}, \\
\mathrm{Na}_{2} \mathrm{SO}_{4}\end{array}$ \\
\hline Mullite & $\begin{array}{l}\mathrm{Na}_{2} \mathrm{SO}_{4} / 100 \\
\mathrm{ppm} \mathrm{SO}_{2}-\mathrm{O}_{2}\end{array}$ & $3.04 \times 10^{-11}$ & $\begin{array}{l}\text { Mullite, } \\
\mathrm{Al}_{2} \mathrm{O}_{3}, \\
\mathrm{NAS}_{6}, \mathrm{NAS}_{2}\end{array}$ & $\begin{array}{l}\text { Mullite, } \\
\mathrm{Na}_{2} \mathrm{SO}_{4}\end{array}$ \\
\hline Mullite & $\begin{array}{l}\mathrm{Na}_{2} \mathrm{SO}_{4} / 10 \\
\mathrm{ppm} \\
\mathrm{SO}_{2}-\mathrm{O}_{2}\end{array}$ & $2.74 \times 10^{-10}$ & $\begin{array}{l}\text { Mullite, } \\
\mathrm{Al}_{2} \mathrm{O}_{3}, \\
\mathrm{NAS}_{6}, \mathrm{NAS}_{2}\end{array}$ & $\begin{array}{l}\text { Mullite, } \\
\mathrm{Al}_{2} \mathrm{O}_{3}, \mathrm{NAS}_{2}\end{array}$ \\
\hline Mullite & $\mathrm{Na}_{2} \mathrm{CO}_{3} / \mathrm{CO}_{2}$ & $8.06 \times 10^{-7}$ & $\begin{array}{l}\text { Mullite, } \\
\mathrm{Al}_{2} \mathrm{O}_{3}, \\
\mathrm{NAS}_{6} \\
\mathrm{NAS}_{21}, \beta- \\
\mathrm{Al}_{2} \mathrm{O}_{3}, \\
\mathrm{NaAlO}_{2} \\
\end{array}$ & $\begin{array}{l}\text { Mullite, } \\
\mathrm{N}_{3} \mathrm{~A}_{2} \mathrm{~S}_{4}\end{array}$ \\
\hline
\end{tabular}

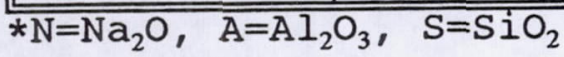




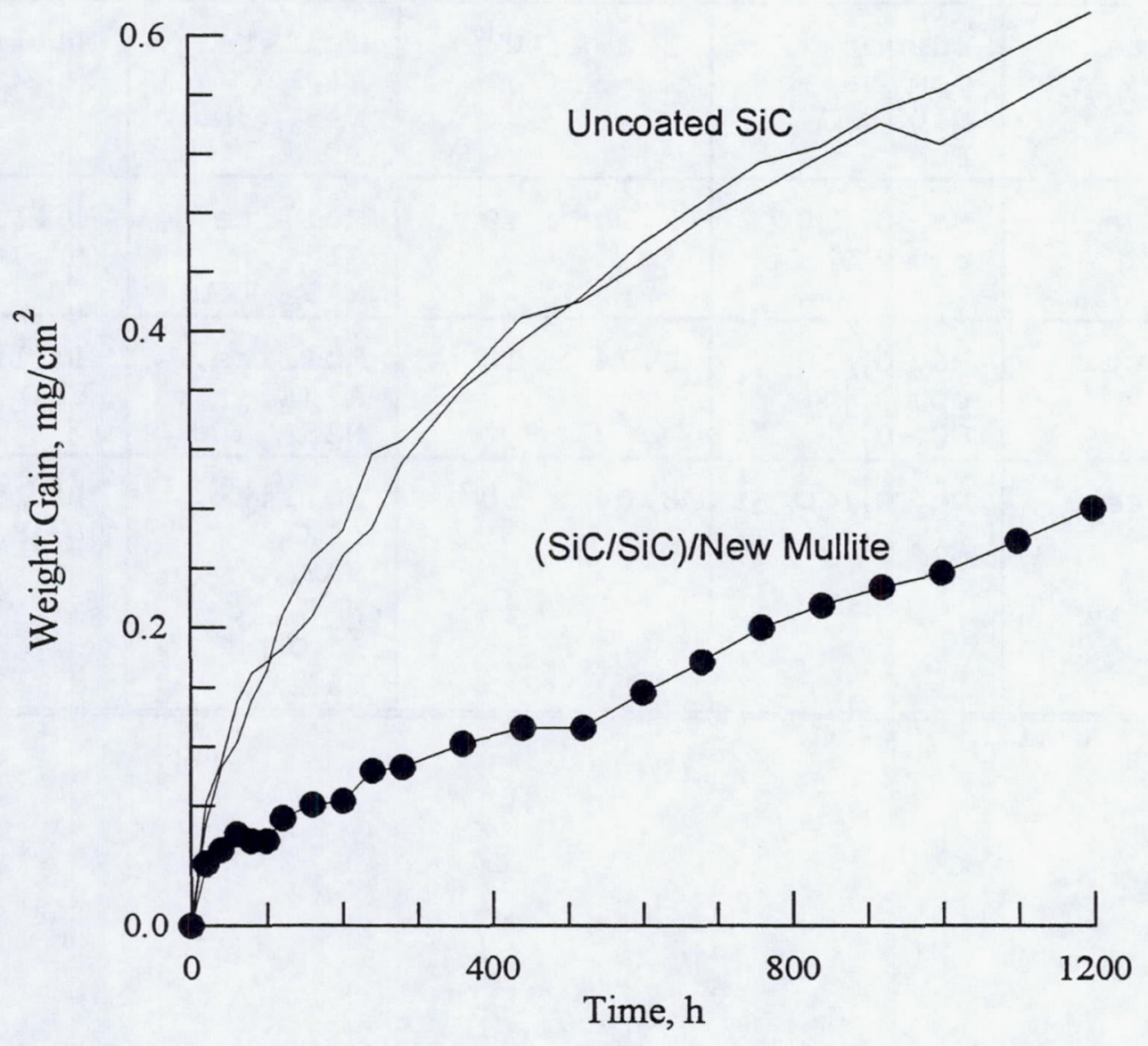

Fig. 1. Cyclic oxidation of $\mathrm{SiC}$ and mullite-coated $\mathrm{SiC} / \mathrm{SiC}$ at $1200^{\circ} \mathrm{C}$ with $20 \mathrm{~h}$ cycle. 


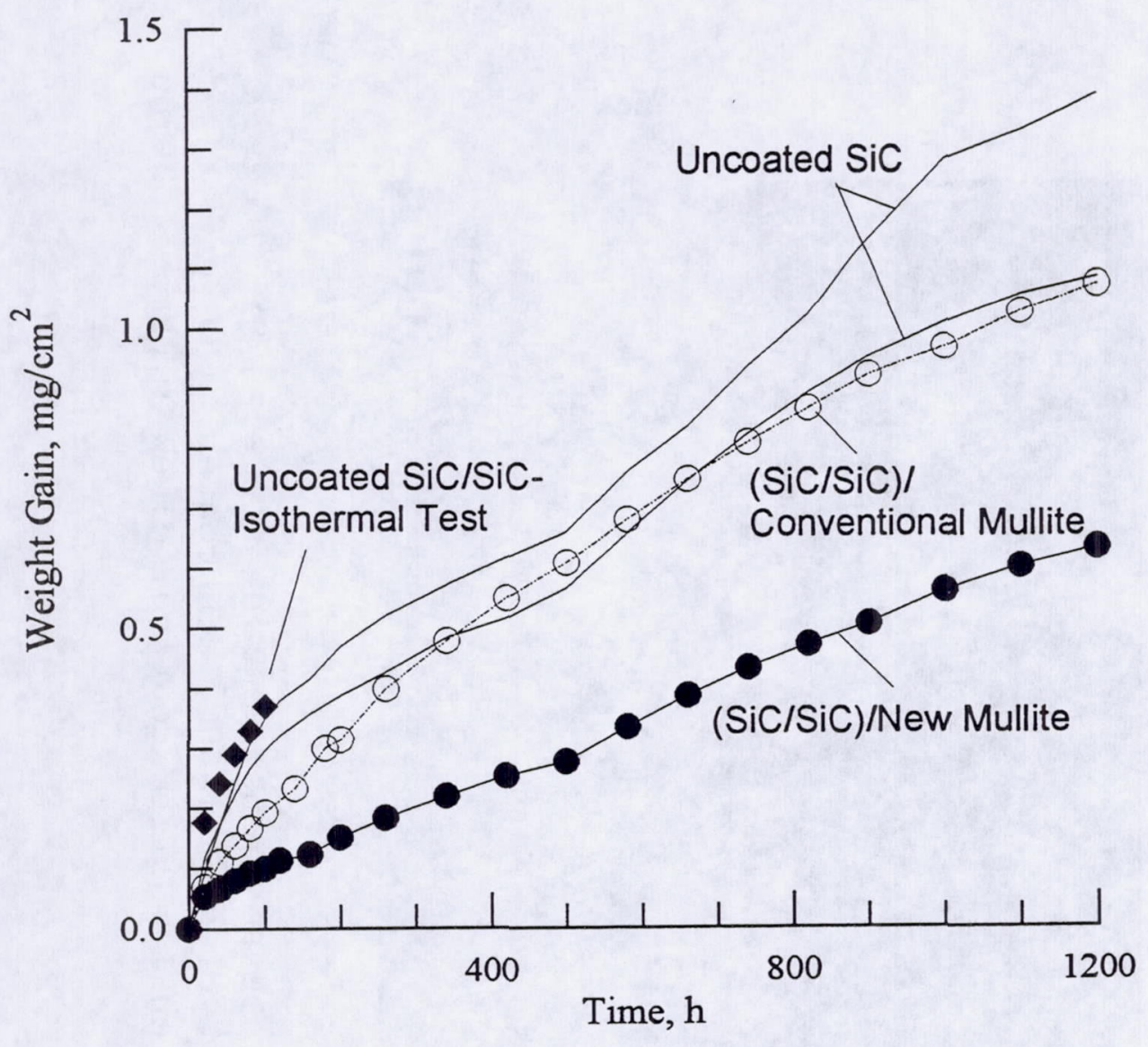

Fig. 2. Cyclic oxidation of $\mathrm{SiC}$ and mullite-coated $\mathrm{SiC} / \mathrm{SiC}$ at $1300^{\circ} \mathrm{C}$ with $20 \mathrm{~h}$ cycle. 


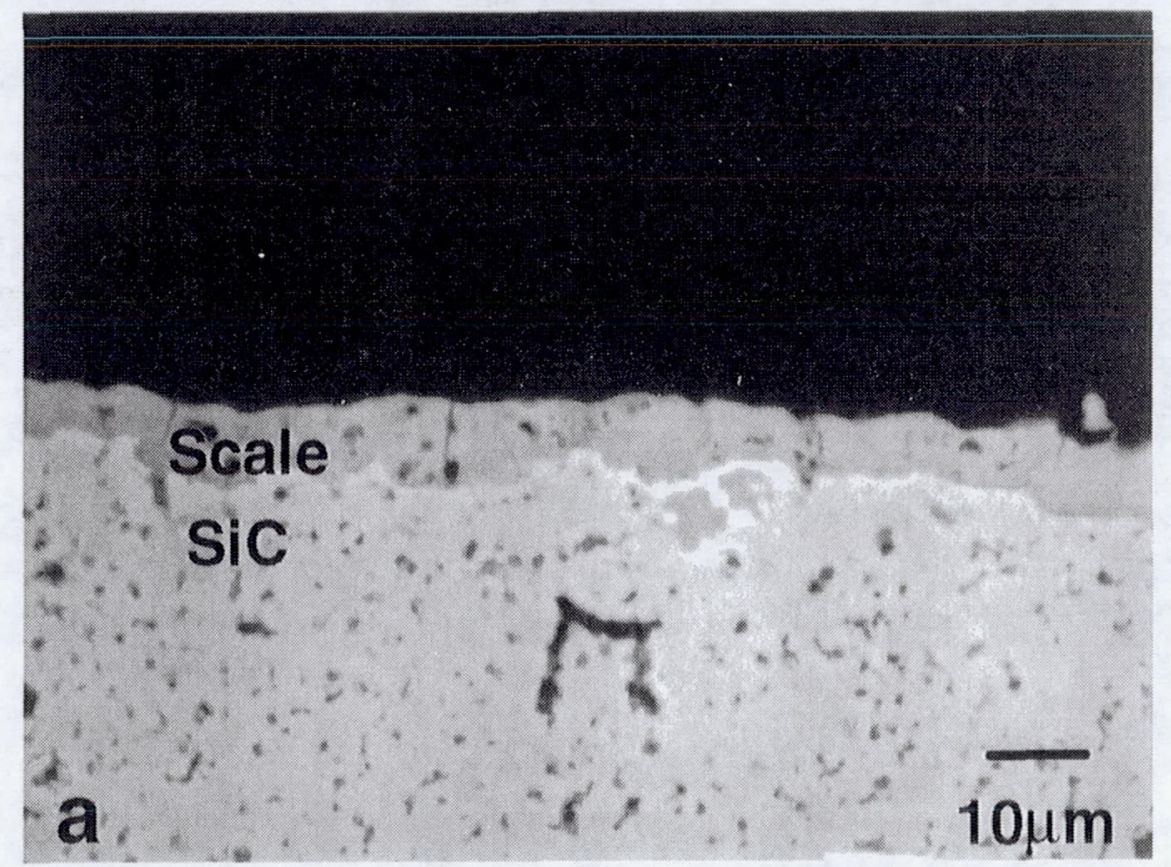

Fig. 3. Cross sections of oxide scale on SiC after sixty 20h-cycles at $1300 \mathrm{C}$. a:uncoated;

$\mathrm{b}$ : conventional mullite coating; $\mathrm{c}$ :new mullite coating. 


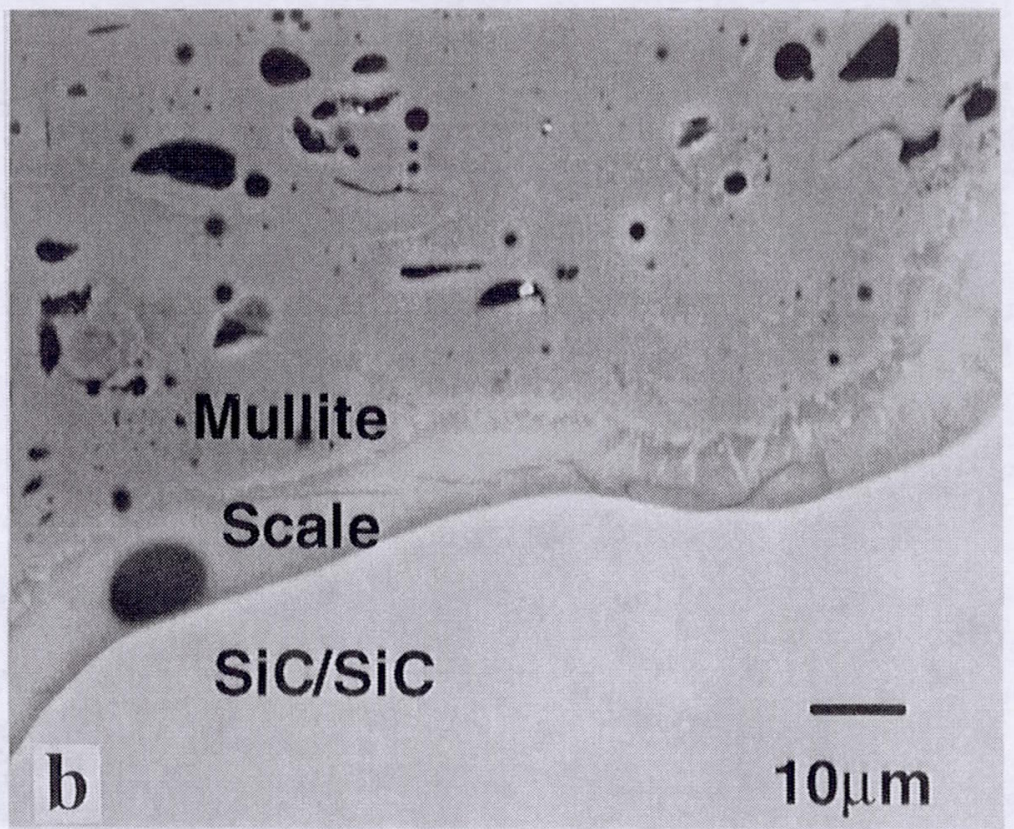

Fig. 3. Continued 


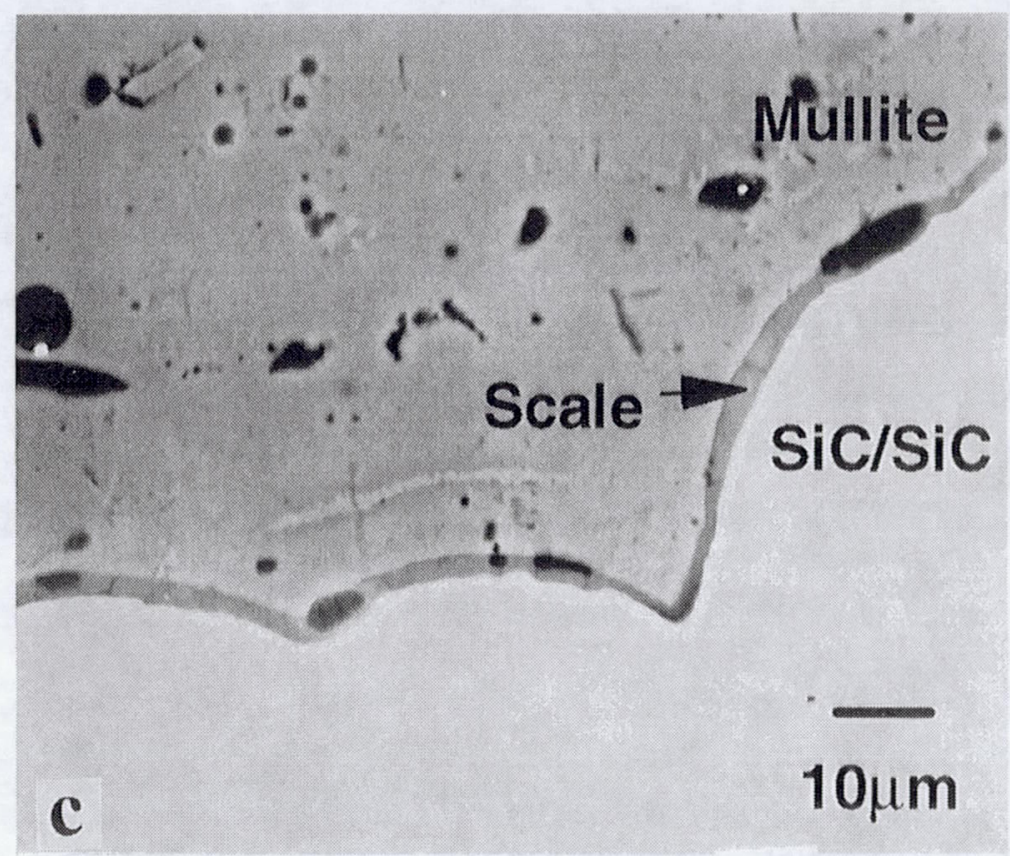

Fig. 3. Continued 


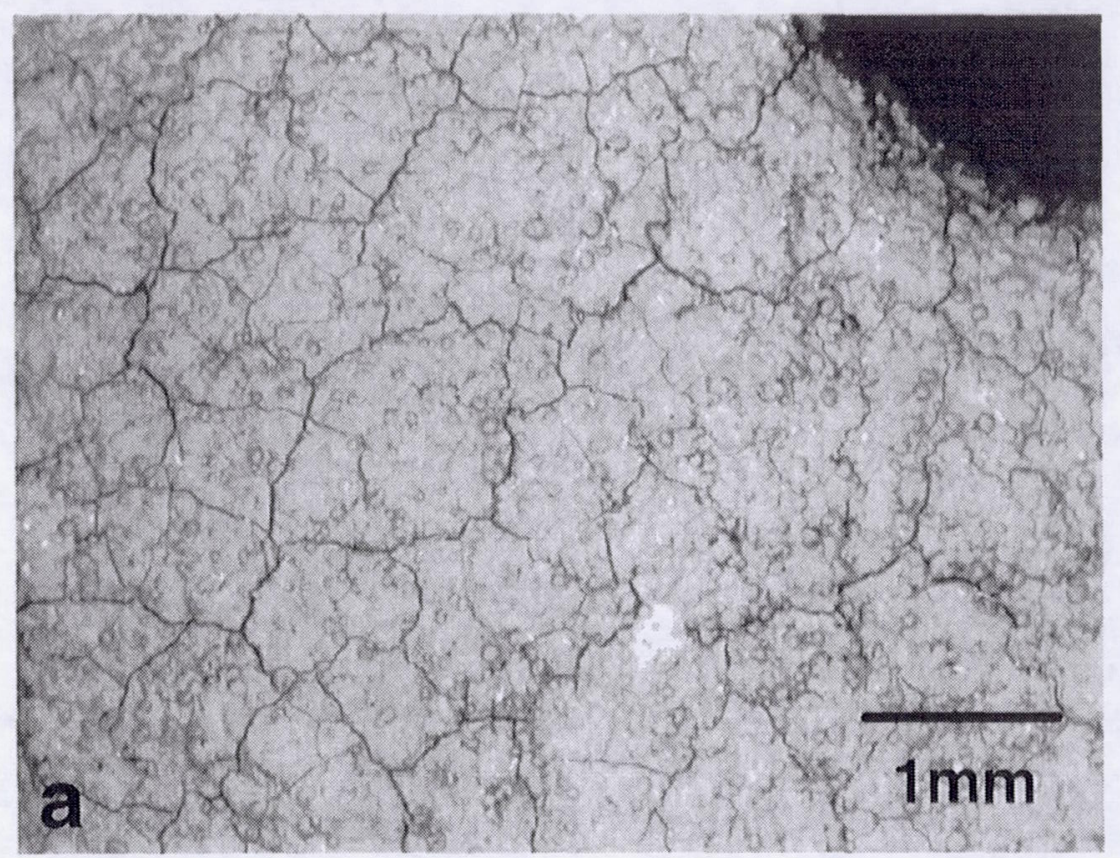

Fig. 4. Surface of mullite coating on $\mathrm{SiC} / \mathrm{SiC}$ after sixty $20 \mathrm{~h}$-cycles at $1300 \mathrm{C}$. a: conventional mullite coating; b: new mullite coating. 


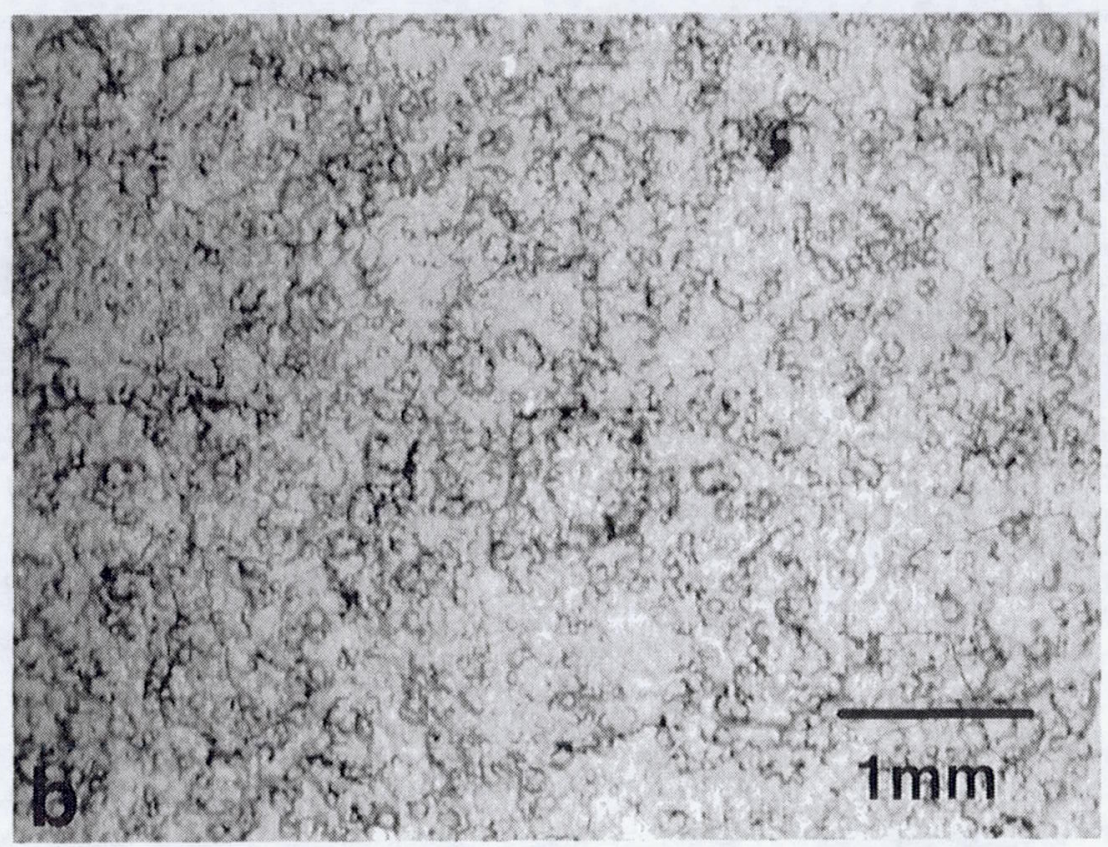

Fig. 4. Continued. 


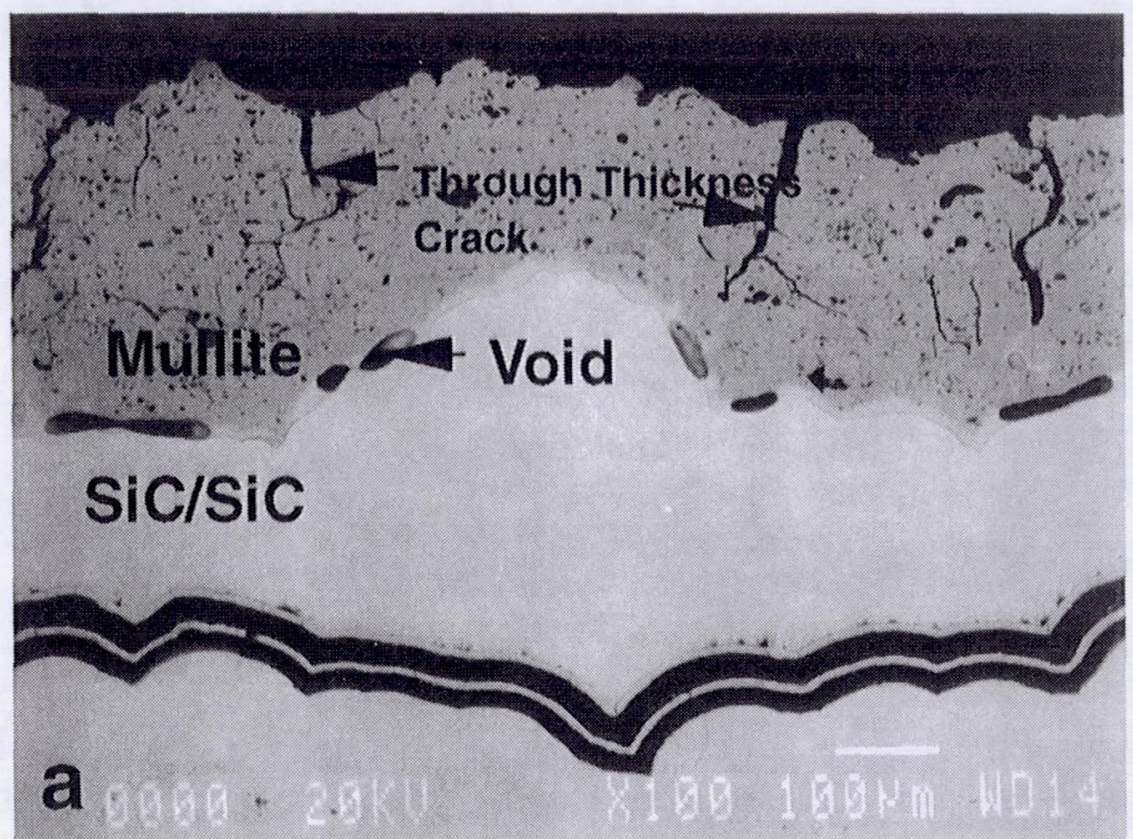

Fig. 5. Cross sections of mullite coating on $\mathrm{SiC} / \mathrm{SiC}$ after sixty $20 \mathrm{~h}-$ cycles at 1300C. a:conventional mullite coating; b:new mullite coating. 


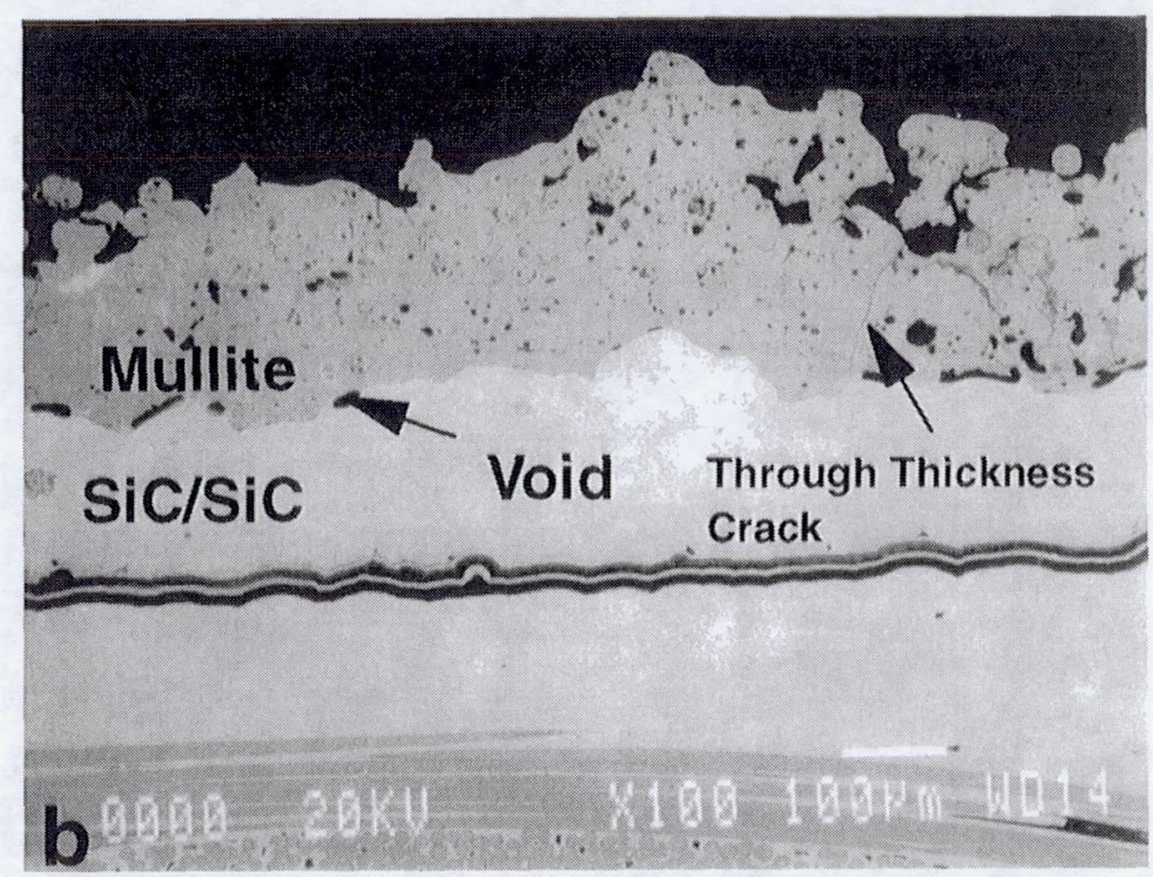

Fig. 5. Continued. 


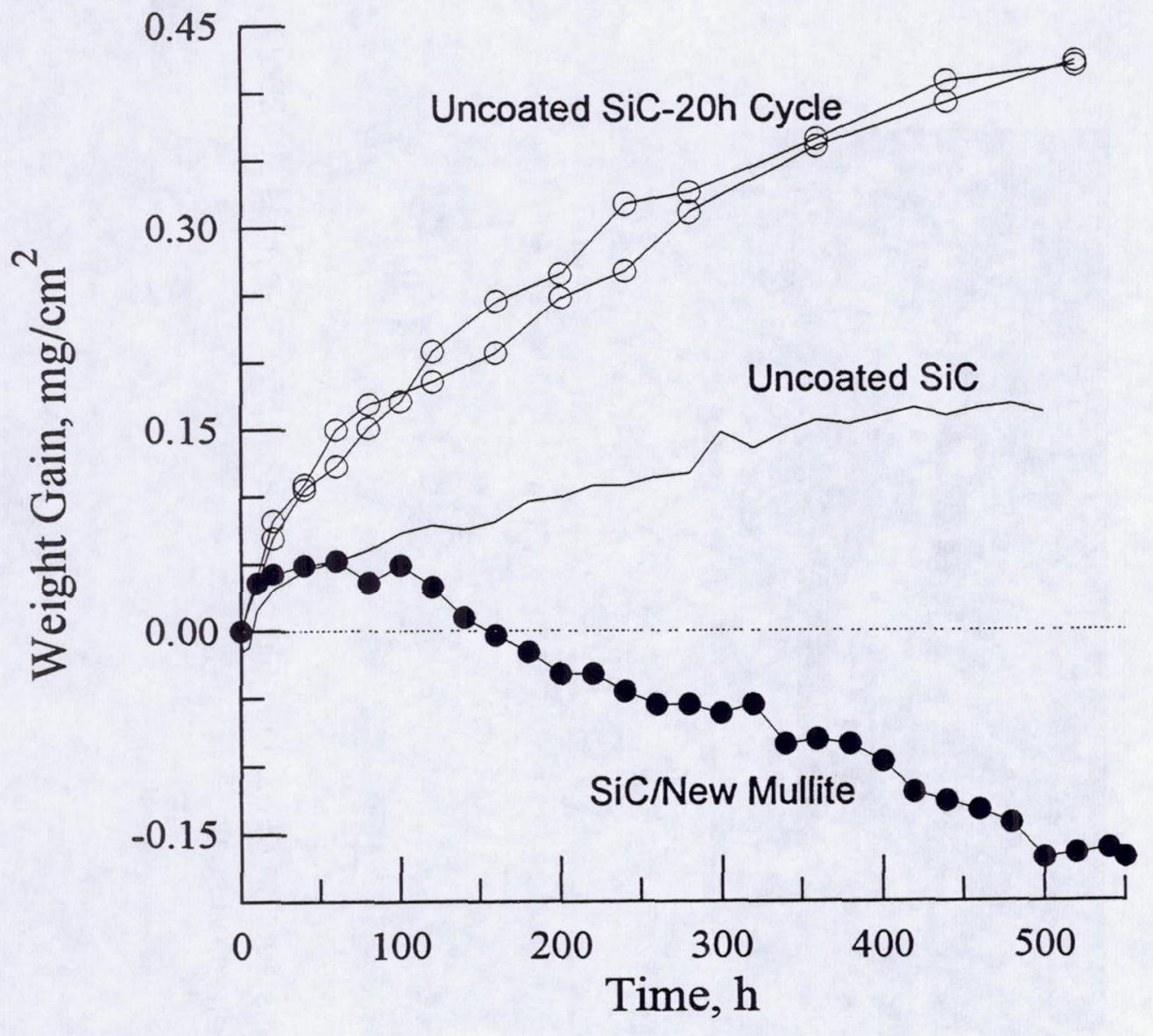

Fig.6 Cyclic oxidation of $\mathrm{SiC}$ and mullite-coated $\mathrm{SiC}$ at $1200^{\circ} \mathrm{C}$ with $1 \mathrm{~h}$ cycle. 


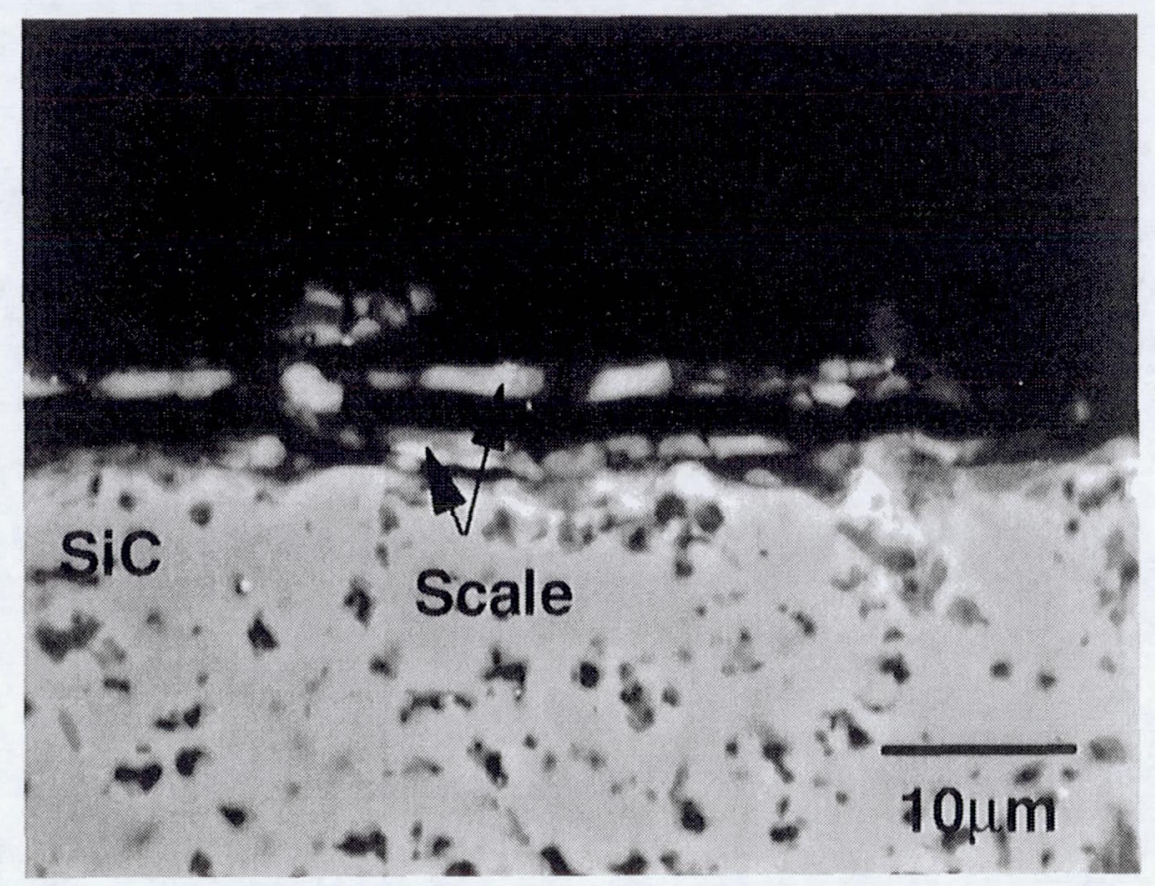

Fig. 7. Cross section of oxide scale on SiC after 550 1h-cycles at 1200C, showing detached scale. 


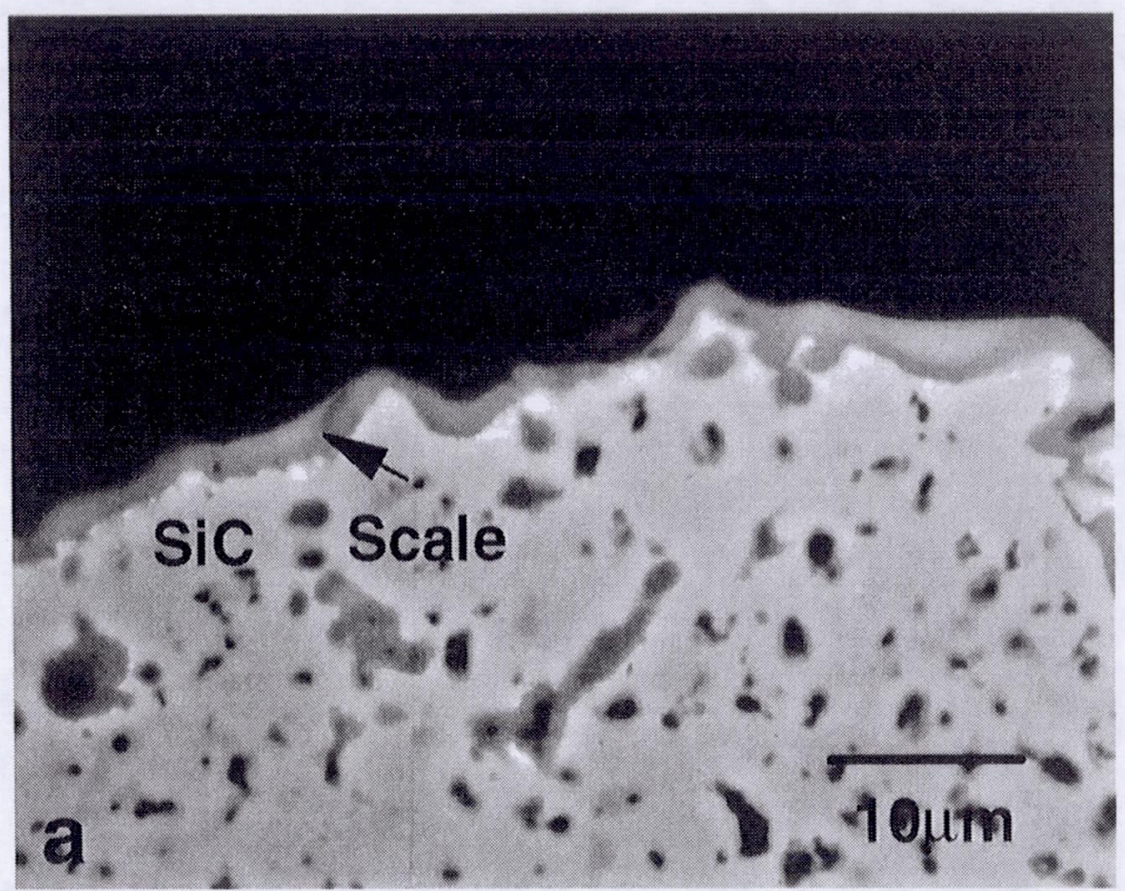

Fig. 8. Cross sections of oxide scale on SiC after 550 1h-cycles at $1200 \mathrm{C}$ a:uncoated; b:new mullite coating 


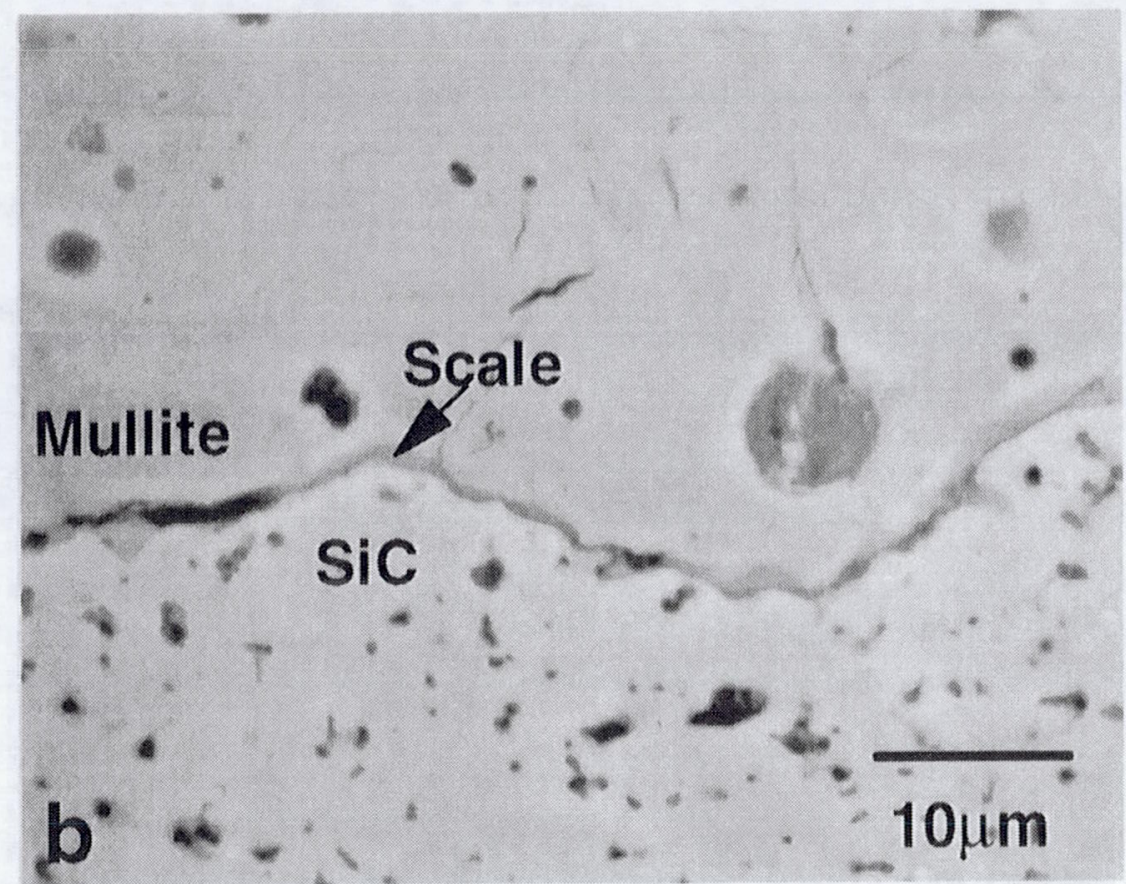

Fig. 8. Continued. 


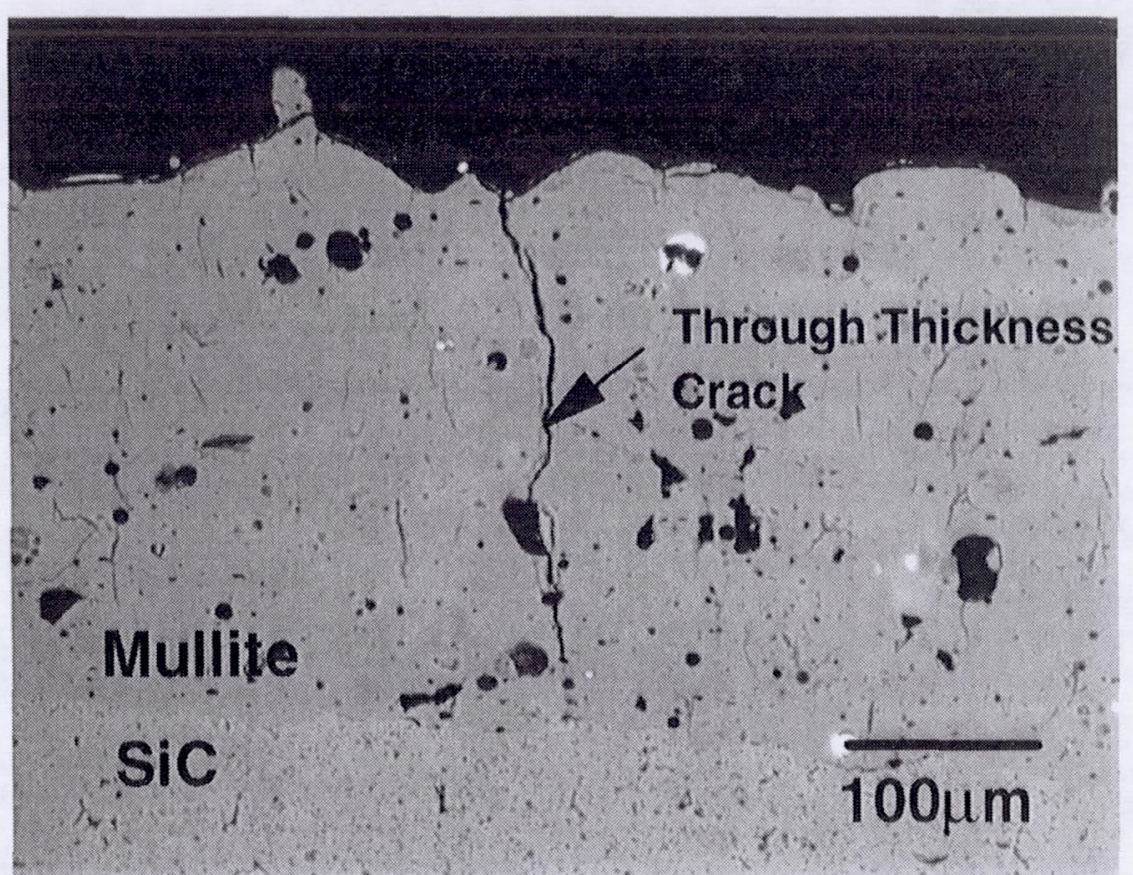

Fig. 9. Cross section of mullite coating on SiC after 550 1h-cycles at $1200 \mathrm{C}$. 
Flux of $\mathrm{SiO}(\mathrm{g})$

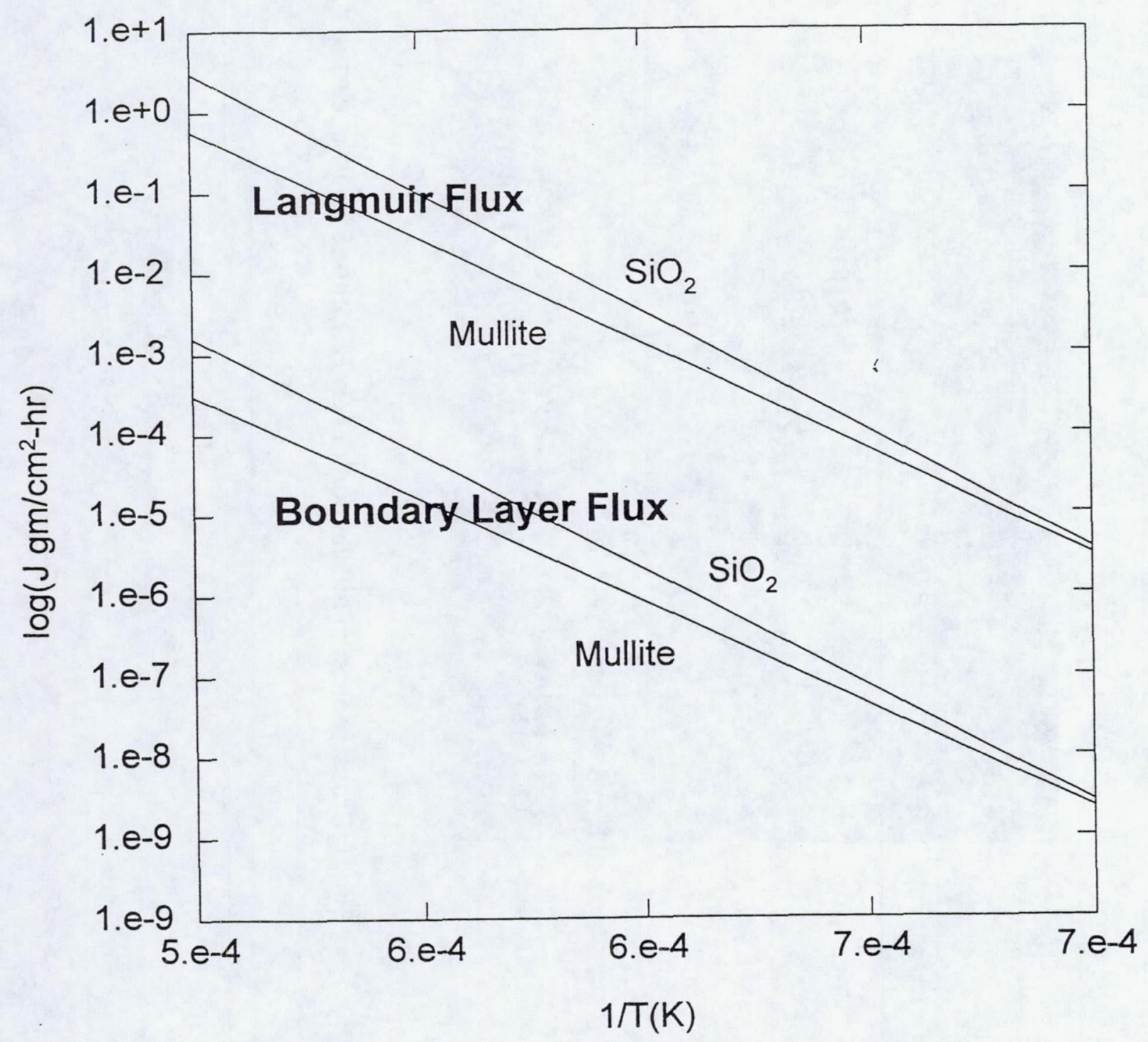

Fig. 10. Flux of $\mathrm{SiO}(\mathrm{g})$ leaving the surface of silica and mullite. 


\section{$\mathrm{Na}_{2} \mathrm{O}+$ Mullite}

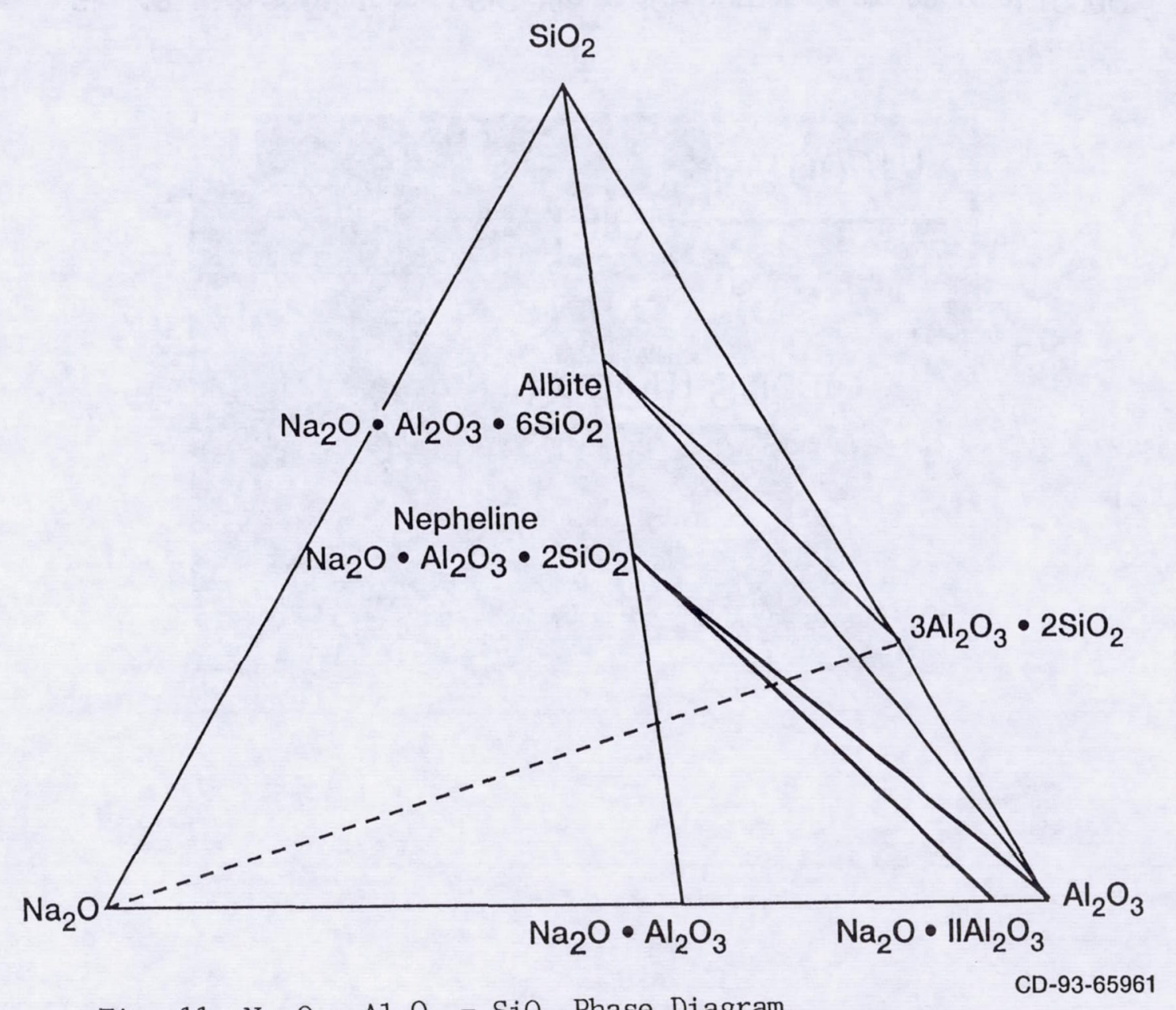

Fig. 11. $\mathrm{Na}_{2} \mathrm{O}-\mathrm{Al}_{2} \mathrm{O}_{3}-\mathrm{SiO}_{2}$ Phase Diagram. 


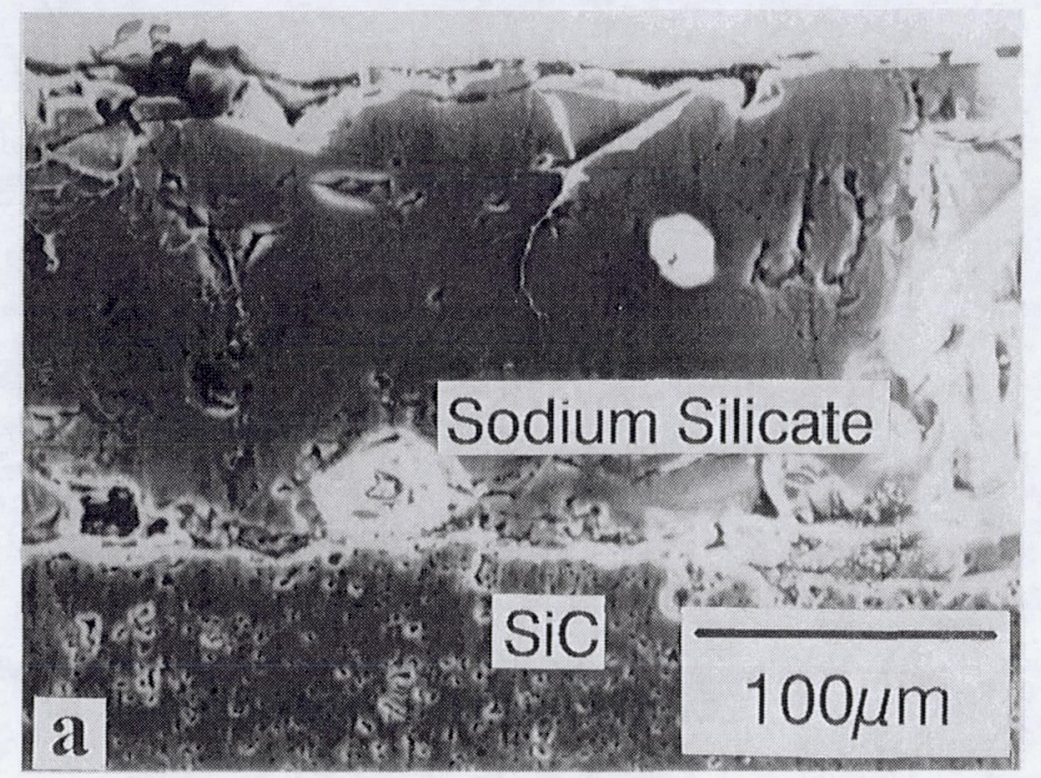

Fig. 12. Cross sections of $\mathrm{SiC}$ after a 40h-burner rig exposure at $1000 \mathrm{C}$ in Jet $\mathrm{A}$ fuel containing $2 \mathrm{ppm} \mathrm{Na}$. a: uncoated; b: new mullite coating. 


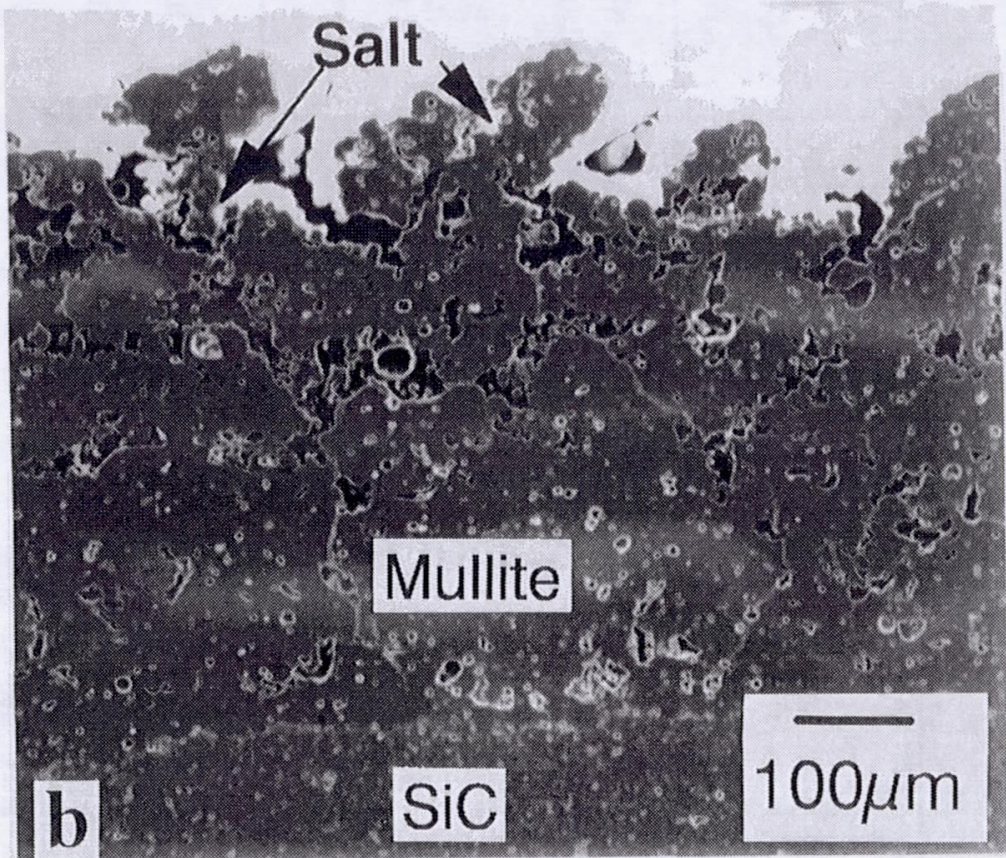

Fig. 12. Continued 
Public reporting burden for this collection of information is estimated to average 1 hour per response, including the time for reviewing instructions, searching existing data sources, gathering and maintaining the data needed, and completing and reviewing the collection of information. Send comments regarding this burden estimate or any other aspect of this collection of information, including suggestions for reducing this burden, to Washington Headquarters Services, Directorate for Information Operations and Reports, 1215 Jefferson Davis Highway, Suite 1204, Arlington, VA 22202-4302, and to the Office of Management and Budget, Paperwork Reduction Project (0704-0188), Washington, DC 20503.

\begin{tabular}{|l|c|c|}
\hline 1. AGENCY USE ONLY (Leave blank) & $\begin{array}{c}\text { 2. REPORT DATE } \\
\text { August } 1994\end{array}$ & $\begin{array}{r}\text { 3. REPORT TYPE AND DATES COVERED } \\
\text { Technical Memorandum }\end{array}$
\end{tabular}

\section{TITLE AND SUBTITLE}

Refractory Oxide Coatings on SiC Ceramics

6. AUTHOR(S)

Kang N. Lee, Nathan S. Jacobson, and Robert A. Miller

7. PERFORMING ORGANIZATION NAME(S) AND ADDRESS(ES)

National Aeronautics and Space Administration

Lewis Research Center

Cleveland, Ohio 44135-3191

9. SPONSORING/MONITORING AGENCY NAME(S) AND ADDRESS(ES)

National Aeronautics and Space Administration

Washington, D.C. 20546-0001
5. FUNDING NUMBERS

WU-778-32-21

8. PERFORMING ORGANIZATION REPORT NUMBER

E-9013

10. SPONSORING/MONITORING AGENCY REPORT NUMBER

NASA TM-106677

11. SUPPLEMENTARY NOTES

Kang N. Lee, Cleveland State University, Cleveland, Ohio 44115 and NASA Resident Research Associate at Lewis Research Center; Nathan S. Jacobson and Robert A. Miller, NASA Lewis Research Center. Responsible person, Kang N. Lee, organization code 5160, (216) 433-5634.

12a. DISTRIBUTION/AVAILABILITY STATEMENT 12b. DISTRIBUTION CODE

Unclassified - Unlimited

Subject Categories 23 and 24

13. ABSTRACT (Maximum 200 words)

Silicon carbide with a refractory oxide coating is potentially a very attractive ceramic system. It offers the desirable mechanical and physical properties of $\mathrm{SiC}$ and the environmental durability of a refractory oxide. The development of a thermal shock resistant plasma-sprayed mullite coating on $\mathrm{SiC}$ is discussed. The durability of the mullite/SiC in oxidizing, reducing, and molten salt environments is discussed. In general, this system exhibits better behavior than uncoated $\mathrm{SiC}$. Areas for further developments are discussed.

14. SUBJECT TERMS

SiC; Refractory oxide; Mullite; Coating

15. NUMBER OF PAGES

\begin{tabular}{|c|c|c|}
\hline $\begin{array}{c}\text { 17. SECURITY CLASSIFICATION } \\
\text { OF REPORT } \\
\begin{array}{c}\text { Unclassified } \\
\text { Unc. SECURITY CLASSIFICATION } \\
\text { OF THIS PAGE } \\
\text { Unclassified }\end{array}\end{array}$ & $\begin{array}{c}\text { 19. SECURITY CLASSIFICATION } \\
\text { OF ABSTRACT } \\
\text { Unclassified }\end{array}$
\end{tabular}

